\title{
Efficacy of longterm interferon treatment in chronic liver disease evaluated by sensitive polymerase chain reaction assay for hepatitis $C$ virus RNA
}

\author{
O Yokosuka, N Kato, K Hosoda, Y Ito, F Imazeki, M Ohto, M Omata
}

\begin{abstract}
Effects of interferon treatment on hepatitis $C$ virus were examined by investigating the presence of hepatitis $C$ virus ribonucleic acid and anti-hepatitis $C$ virus antibody in 70 patients with non- $A$, non-B chronic liver diseases. Twenty one patients were treated with three million units of interferon alfa 2 a three times a week for 52 weeks, 24 patients were treated similarly for eight weeks, and 25 patients were given a placebo for eight weeks and served as control. Sixty six of 70 patients (94\%) were positive for both hepatitis C virus RNA and second generation antihepatitis $\mathrm{C}$ virus antibody. Fourteen of 21 $(67 \%)$ receiving the longterm treatment had a normalised alanine aminotransferase (ALT) activity, and in 12 of these hepatitis $C$ virus ribonucleic acid became undetectable by the end of treatment and remained so during the three year follow up after the treatment. Anti-hepatitis C virus antibody determined by first generation assay became negative in one case at the end of the 52 week treatment, and in four cases at the end of the one year follow up. In contrast, only one of $24(4 \%)$ who received the eight week treatment and only one of $25(4 \%)$ who received the placebo had normalised ALT activities. Hepatitis $C$ virus ribonucleic acid became negative in two patients undergoing shortterm treatment and in none receiving the placebo. Thus, longterm interferon treatment seems effective in clearing hepatitis $C$ virus from serum of patients with chronic liver disease.

(Gut 1995; 37: 721-726)
\end{abstract}

Keywords: HCV RNA, chronic hepatitis, interferon treatment, polymerase chain reaction, anti-HCV antibody.

Non-A, non-B chronic hepatitis is a common liver disease and often progresses to liver cirrhosis and hepatocellular carcinoma. ${ }^{12}$ Hoofnagle et al have shown that interferon treatment might be effective for non-A, non-B chronic hepatitis. $^{3}$ We have previously reported that interferon treatment might improve not only biochemical, but also histological abnormalities in non-A, non-B chronic hepatitis. ${ }^{4}$ Recent double blind controlled studies have confirmed that interferon therapy is effective in suppressing the disease activity in many patients. ${ }^{56}$ It has not been established, however, whether the interferon treatment is also able to clear the virus from serum. The recent success in cloning hepatitis $C$ virus (HCV) ribonucleic acid (RNA) ${ }^{7}$ has led to the development of an assay procedure for antiHCV antibody. $8{ }^{8}$ It has also led to a sensitive assay system for detecting HCV RNA with the use of reverse transcription-polymerase chain reaction (RT-PCR). ${ }^{10-12}$ In this study we examined the changes of HCV RNA and antiHCV antibody in patients with non-A, non-B chronic liver disease who were treated by interferon alfa $2 \mathrm{a}$ and investigated the effect of the treatment on HCV.

\section{Methods}

\section{Patients and materials}

Seventy patients admitted to the Chiba University Hospital between November 1986 and December 1988 and fulfilling the criteria for diagnosis of non-A, non-B chronic liver disease were studied. These criteria were: (a) serum aminotransferase increases greater than twofold (80 IU/l) the upper limits of normal for more than two months; (b) liver biopsy (taken within six months before entry) showing histological features of chronic inflammatory disease; (c) no $\mathrm{HBsAg}$ and $\mathrm{HBV}$ DNA detectable in serum using radioimmunoassay and spot hybridisation, respectively; (d) serum autoantibodies (anti-nuclear antibody, anti-smooth muscle antibody, anti-mitochondrial antibody) negative or only weakly positive; (e) no history of alcohol misuse or other known cause of liver disease.

These patients were randomly assigned to one of the following three treatment regimens by opening a sealed envelope indicating a treatment regimen at the time of entry to this study. The patients each freely chose one such envelope from 99 envelopes that had been previously prepared and kept by a study monitor (YI) who was not involved in patient care.

Of these 70 patients, 21 were treated with three million units of recombinant interferon alfa $2 \mathrm{a}$ three times per week for 52 weeks (group 1), and 24 were similarly treated for eight weeks (group 2). The other 25 were given a placebo for eight weeks (group 3). Table I shows the clinical data of these three groups. Serum samples from these 70 patients were analysed before, during, at the end, and after 
TABLE I Clinical data of patients receiving longterm and short-term interferon and placebo

\begin{tabular}{|c|c|c|c|c|c|c|c|c|c|}
\hline & \multirow[b]{2}{*}{$\begin{array}{l}\text { No of } \\
\text { patients }\end{array}$} & \multirow[b]{2}{*}{$\begin{array}{l}\text { Sex } \\
(M / F)\end{array}$} & \multirow[b]{2}{*}{$A g e^{\star}$} & \multirow[b]{2}{*}{$\begin{array}{l}B T F \\
(+/-)\end{array}$} & \multicolumn{2}{|c|}{ Anti-HCV } & \multirow[b]{2}{*}{$\begin{array}{l}A L T^{\star} \\
(I U /)\end{array}$} & \multirow[b]{2}{*}{$\begin{array}{l}\text { Pretreatment }{ }^{\star} \dagger \\
H C V R N A\end{array}$} & \multirow{2}{*}{$\begin{array}{l}\text { Histology } \\
\text { (CPH/ } \\
\text { CAH/Cir) }\end{array}$} \\
\hline & & & & & $\begin{array}{l}\text { First } \\
(+/-)\end{array}$ & $\begin{array}{l}\text { Second } \\
(+/-)\end{array}$ & & & \\
\hline Longterm treatment (group 1) & 21 & $12 / 9$ & $48(9)$ & $10 / 11$ & $14 / 7$ & $21 / 0$ & $192(104)$ & $10^{4 \cdot 6(1 \cdot 9)}$ & $4 / 15 / 2$ \\
\hline Short-term treatment (group 2) & 24 & $15 / 9$ & $53(9)$ & $12 / 12$ & $17 / 7$ & $22 / 2$ & $155(91)$ & $10^{4 \cdot 3(2 \cdot 1)}$ & $3 / 18 / 3$ \\
\hline Type C & 22 & $13 / 9$ & $53(9)$ & $12 / 10$ & $17 / 5$ & $22 / 0$ & $159(93)$ & $10^{4 \cdot 7(1 \cdot 7)}$ & $3 / 16 / 3$ \\
\hline Type non-C & 2 & $2 / 0$ & $52(1)$ & $0 / 2$ & $0 / 2$ & $0 / 2$ & $109(19)$ & - ve & $0 / 2 / 0$ \\
\hline Untreated control (group 3) & 25 & $16 / 9$ & $47(12)$ & $12 / 13$ & $18 / 7$ & $23 / 2$ & $158(140)$ & $10^{4 \cdot 3(1 \cdot 8)}$ & $6 / 19 / 0$ \\
\hline Type C & 23 & $15 / 8$ & 49 (11) & $12 / 11$ & $18 / 5$ & $23 / 0$ & $157(146)$ & $10^{4 \cdot 7(1 \cdot 4)}$ & $5 / 18 / 0$ \\
\hline Type non-C & 2 & $1 / 1$ & $27(5)$ & $0 / 2$ & $0 / 2$ & $0 / 2$ & $169(40)$ & - ve & $1 / 1 / 0$ \\
\hline
\end{tabular}

The data shown in the lower parts of groups 2 and 3 are those of patients with and without type C hepatitis. *, mean (SD); BTF, blood transfusion; ALT, alanine aminotransferase; CPH, chronic persistent hepatitis; CAH, chronic active hepatitis; Cir, cirrhosis of the liver; $t$, pretreatment value of HCV RNA (copies $/ 50 \mu l$ ).

the treatment. HCV RNA and anti-HCV antibody were examined every three months during (longterm), before and after (shortterm), and every six months after the treatment. Liver function tests were performed monthly. All the patients were followed up for at least three years after the treatment.

Sixty six of the 70 patients $(94 \%)$ were positive for both HCV RNA and second generation anti-HCV antibody, so virtually all of these patients were HCV carriers (Table I). The remaining four patients were negative for $\mathrm{HCV}$ $\mathrm{RNA}$, first and second generation anti-HCV antibody, and were considered to be non- $\mathrm{A}$, non-B, non-C hepatitis.

All of the $21(100 \%)$ patients with longterm treatment (group 1), 22 of 24 (92\%) patients with short-term treatment (group 2), and 23 of $25(92 \%)$ patients given placebo (group 3 ) were type $C$ hepatitis (Table I). There were no statistical differences in type $C$ hepatitis incidence among the three groups.

Detection of HCV RNA and anti-HCV antibody Serum HCV RNA was detected as we described previously ${ }^{10}$ with several modifications. The important differences compared with other reported methods ${ }^{12-16}$ were as follows. For synthesis of complementary DNA (cDNA) and its amplification, two sets of primers: 'outer' (5'-CACCATAGATCACTCCCCTG-3' and 5'-GCCCAAATCTCCAGGCATTG-3') and 'inner' (5'-AACTACTGTCTTCACGCAGA-3' and $3^{\prime}$-TCCAAGAAAGGACCCGGTCG-3') primers, were prepared in the $5^{\prime}$ non-coding region of HCV. ${ }^{1718}$ A relatively small size of PCR product (150 nucleotides) was expected to be made. Relatively large amounts of reverse transcriptase (15 units) (Takara Shuzo Co, Kyoto, Japan) and Taq polymerase (4 units) (Perkin-Elmer Cetus, Norwalk, CT, USA) were used. Numerous cycles of amplification were performed for both first and second round PCR (35 cycles each) at $95^{\circ} \mathrm{C}-50^{\circ} \mathrm{C}$ $70^{\circ} \mathrm{C}$.

For the determination of the sensitivity of our HCV RNA assay, we amplified a 255 nucleotide sequence of the $5^{\prime}$ non-coding region of $\mathrm{HCV}$ (position -319 to -65 of HCV, ${ }^{14}$ which includes the site for first step PCR of the HCV RNA detection method) by RT-PCR with primers 5'-CACCATAGATCACTCCCCTG-3' and 5'-TTTCGCGACCCAACACTACT $-3^{\prime}$ and cloned the amplified product in pGEM-4Z vector (Promega, Madison, WI, USA), and RNA was generated from the vector with T7 RNA polymerase according to the manufacturer's instructions (Riboprobe Gemini System II; Promega, Madison, WI, USA). Known amounts of the RNA ( $0-5$ attograms, equivalent to $0-25$ copies of $\mathrm{HCV}$ ) were used to determine the sensitivity of the HCV RNA detection method. As two attograms of the RNA were repeatedly detectable, the sensitivity for HCV RNA detection by our method was considered to be less than 10 copies of $\mathrm{HCV}$ in the specimen.

The pretreatment value of HCV RNA in the serum was examined by the competitive RTPCR method as already described by the authors. ${ }^{19}$

Anti-HCV antibody was examined by commercially available first and second generation enzyme linked immunosorbent assay (ELISA) kits (Ortho Diagnostics Systems, Naritan, NJ, USA). Liver function tests were carried out by standard techniques.

\section{Statistical analysis}

The values of age, sex, alanine aminotransferase (ALT) activity and pretreatment value of HCV RNA were expressed as mean (SD). These data were analysed by the Student's $t$ test. The positive rates of HCV RNA and anti-HCV antibody among the three treatment regimens were analysed by $\chi^{2}$ test.

\section{Results}

\section{Effect of interferon alfa $2 a$ treatment on $A L T$} activity

The serum ALT activity became completely normal in 14 of $21(67 \%)$ patients with type C hepatitis by the longterm treatment (group 1) (Figure, left panel). It remained normal in all the 14 cases for more than three years after the end of treatment. In the remaining seven cases it remained abnormal during the observation period.

The serum ALT value became normal during the short-term treatment in seven of 22 $(32 \%)$ patients with hepatitis $\mathrm{C}$ and in none of two patients with non-A, non-B, non-C hepatitis (group 2). In six of seven cases, however, ALT reverted to an abnormal value after the end of treatment, with only one case staying normal (Figure, middle panel). 

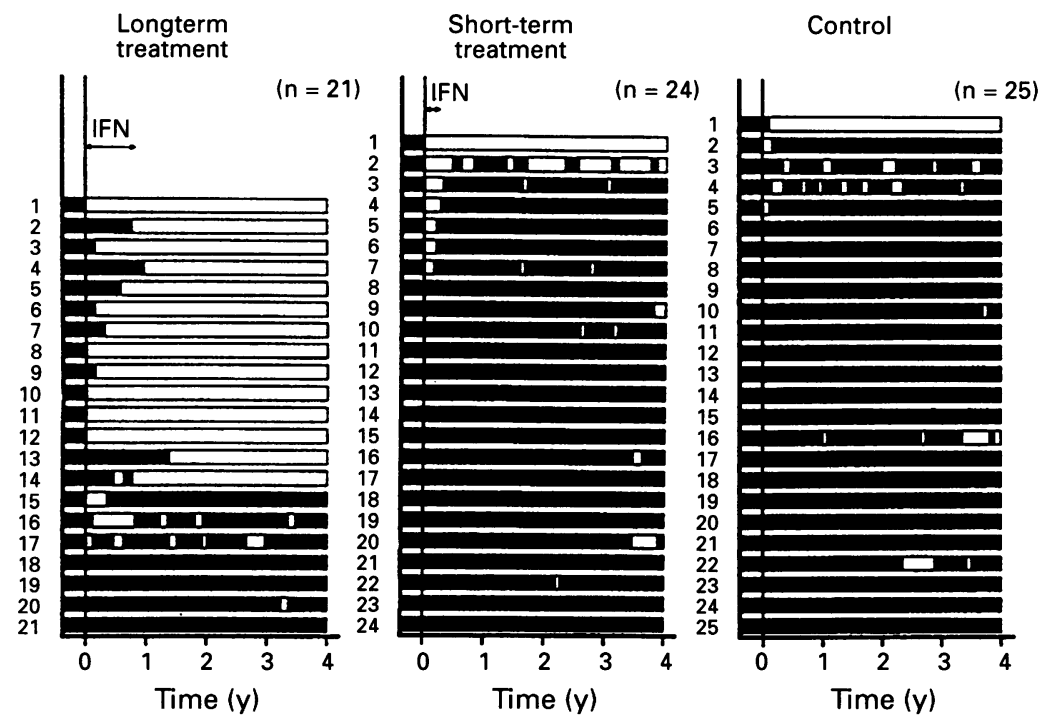

Changes of serum ALT in longterm and short-term treated and control groups from the beginning of treatment to the end of three year follow up. Shaded boxes show periods with abnormal ALT values and blank boxes show periods with completely normalised ALT. Cases 23 and 24 in the short-term treatment group and cases 24 and 25 in the control group were negative for HCV RNA and second generation anti-HCV antibody.

In contrast with these treated cases, the serum ALT value became normal during the placebo administration in only one of $23(4 \%)$ patients with type $C$ hepatitis and in none of two non-A, non-B, non-C patients (group 3) (Figure, right panel).

\section{Effect of interferon alfa $2 a$ on $H C V R N A$}

HCV RNA was positive in all $21(100 \%)$ longterm treated patients before the treatment (Table II) (group 1), becoming undetectable in 12 of them $(57 \%)$ by the end of the treatment (Table III). Serial samples taken from the 12 patients every month during the one year treatment showed that HCV RNA became undetectable within three months after beginning the treatment in three cases, within six months in three other cases, within nine months in another two cases, and within 12 months in the other four cases (Table III). All 12 patients stayed negative for serum $\mathrm{HCV}$ RNA for more than 36 months after the end of the treatment. The ALT activity was normalised in all these 12 cases. In the remaining nine cases, HCV RNA could not be reduced to an undetectable value during the one year treatment, and they also stayed positive for HCV RNA in the serum thereafter (Table III).

Eleven of $12(92 \%)$ patients who showed sustained response to longterm treatment had less than $10^{5}$ copies $/ 50 \mu$ l of pretreatment HCV RNA in the serum, whereas seven of nine $(78 \%)$ patients who did not show the sustained response had more than $10^{6}$ copies $/ 50 \mu l$
(Table III). The mean (SD) amounts of pretreatment HCV RNA of type C patients in the short-term treatment group and in the control group were $10^{4 \cdot 7(1 \cdot 7)}$ copies $/ 50 \mu l$ and $10^{4 \cdot 7(1 \cdot 4)}$ copies $/ 50 \mu$, respectively, not statistically different from that in the long term treatment group $\left(10^{4 \cdot 6(1 \cdot 9)}\right.$ copies/50 $\left.\mu \mathrm{l}\right)$ (Table I).

Of $22 \mathrm{HCV}$ RNA positive patients who underwent the short-term treatment (group 2) (Table II), HCV RNA became undetectable in two cases $(9 \%)$ by the end of this course. In one of these, the ALT value became normal by the end of treatment and remained normal for more than 36 months thereafter. In the other case, however, the ALT value was normal for four months, only to turn mildly abnormal thereafter, fluctuating between normal and abnormal values (Figure, middle panel, case 2). In five of seven cases in which ALT activities transiently normalised during the treatment, HCV RNA significantly decreased, but then increased again after the end of treatment.

In $23 \mathrm{HCV}$ RNA positive patients given the placebo (group 3), none became negative for HCV RNA during the observation period (Table II).

\section{Effect of interferon alfa on anti-HCV antibody}

First generation anti-HCV antibody was positive in 49 of $66(74 \%)$ type $C$ patients before the treatment. It was positive in 14 of $21(67 \%)$ type $\mathrm{C}$ patients in the longterm treatment group (group 1, Table I). It became negative in one (case 3 of Table III) of $14(7 \%)$ by the end of the treatment, and in another three (cases 4,5 , 6 of Table III) (21\%) 12 months after the treatment had finished (Table III). HCV RNA had become undetectable in all these four cases before the anti-HCV antibody became negative.

First generation anti-HCV antibody was positive in 17 of $22(77 \%)$ type $C$ patients with short-term treatment (group 2, Table I). It was also positive in 18 of $23(78 \%)$ type $C$ patients given the placebo (group 3, Table I). In none of these group 2 and 3 patients did the first generation anti-HCV antibody become negative during the follow up observation period. There were no statistically significant differences in the positive rate of first generation anti-HCV antibody among these three groups before and after the treatment.

Second generation anti-HCV antibody became negative in none of the 66 type $C$ patients during and after the treatment.

\section{Discussion}

Several studies on the treatment of non-A, non-B hepatitis with interferon alfa have been

TABLE II Changes in the numbers (\%) of HCV RNA positive cases in type $C$ patients from each group before, at the end, one year, two years, and three years after the end of interferon treatment

\begin{tabular}{llcccc}
\hline & $\begin{array}{l}\text { Before } \\
\text { treatment }\end{array}$ & $\begin{array}{l}\text { At end of } \\
\text { treatment }\end{array}$ & $\begin{array}{l}\text { One year after } \\
\text { end of treatment }\end{array}$ & $\begin{array}{l}\text { Two years after } \\
\text { end of treatment }\end{array}$ & $\begin{array}{r}\text { Three years after } \\
\text { end of treatment }\end{array}$ \\
\hline Longterm treatment (group 1) & $21 / 21(100)$ & $9 / 21(43)^{\star} \dagger$ & $9 / 21(43)^{\star} \dagger$ & $9 / 21(43)^{\star} \dagger$ & $9 / 21(43)^{\star} \dagger$ \\
Short-term treatment (group 2) & $22 / 22(100)$ & $20 / 22(91)^{\star}$ & $20 / 22(91)^{\star}$ & $20 / 22(91)^{\star}$ & $20 / 22(91)^{\star}$ \\
Untreated control (group 3) & $23 / 23(100)$ & $23 / 23(100) \dagger$ & $23 / 23(100) \dagger$ & $23 / 23(100) \dagger$ & $23 / 23(100) \dagger$ \\
\hline
\end{tabular}

${ }^{\star}: \mathrm{p}<0.05$ and $\dagger: \mathrm{p}<0.01$ by $\chi^{2}$ test. 
TABLE III Clinical data and changes of HCV RNA in patients receiving longterm interferon alfa $2 a$ treatment

\begin{tabular}{|c|c|c|c|c|c|c|c|c|c|c|c|c|c|}
\hline Patient & Sex & Age & Hist & $B T F$ & $H-R$ & Before & $-3 m$ & $-6 m$ & $-9 m$ & $\begin{array}{l}-12 m \\
\text { (end) }\end{array}$ & $-2 y$ & $-3 y$ & $-4 y$ \\
\hline 1 & $M$ & 55 & CPH & + & $10^{1}$ & + & $-\star$ & - & - & - & - & - & - \\
\hline 3 & M & 52 & CAH & - & $10^{1}$ & + & $-\star$ & - & - & $-\dagger$ & - & - & - \\
\hline 10 & $\mathbf{F}$ & 35 & $\mathrm{CAH}$ & - & $10^{1}$ & + & $-\star$ & - & - & - & - & - & - \\
\hline 4 & M & 42 & $\mathrm{CAH}$ & + & $10^{3}$ & + & + & - & - & $-t$ & $-{ }^{\star} \dagger$ & - & - \\
\hline 6 & $\mathrm{~F}$ & 58 & $\mathrm{Cir}$ & + & $10^{4}$ & + & 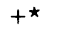 & - & - & $-t$ & $-t$ & - & - \\
\hline 11 & $\mathrm{~F}$ & 35 & CPH & + & $10^{3}$ & + & $+^{\star}$ & - & - & - & - & - & - \\
\hline 5 & $\mathrm{~F}$ & 57 & $\mathrm{CPH}$ & - & $10^{3}$ & + & + & + & $-\star$ & - & $-t$ & - & - \\
\hline 8 & M & 35 & $\mathrm{CAH}$ & - & $10^{4}$ & + & $+\star$ & + & - & - & - & - & - \\
\hline 2 & $\mathrm{~F}$ & 42 & $\mathrm{CAH}$ & + & $10^{6}$ & + & + & + & + & $-\star$ & - & - & - \\
\hline 7 & $\mathbf{M}$ & 57 & CAH & + & $10^{5}$ & + & + & $+\star$ & + & - & - & - & - \\
\hline 9 & M & 41 & CAH & - & $10^{4}$ & + & $+^{\star}$ & + & + & - & - & - & - \\
\hline 12 & $\mathrm{~F}$ & 46 & $\mathrm{CAH}$ & - & $10^{5}$ & + & $+^{\star}$ & + & + & - & - & - & - \\
\hline 13 & M & 54 & Cir & - & $10^{7}$ & + & + & + & + & + & $t^{\star}$ & + & + \\
\hline 14 & $\mathbf{M}$ & 51 & $\mathrm{CAH}$ & + & $10^{6}$ & + & + & + & + & $+^{\star}$ & + & + & + \\
\hline 15 & $\mathrm{~F}$ & 64 & CAH & + & $10^{7}$ & + & + & + & + & + & + & + & + \\
\hline 16 & M & 42 & CPH & + & $10^{6}$ & + & + & + & + & + & + & + & + \\
\hline 17 & $\mathrm{~F}$ & 38 & CAH & - & $10^{5}$ & + & + & + & + & + & + & + & + \\
\hline 18 & $\mathbf{M}$ & 55 & $\mathrm{CAH}$ & - & $10^{7}$ & + & + & + & + & + & + & + & + \\
\hline 19 & $\mathrm{~F}$ & 59 & $\mathrm{CAH}$ & + & $10^{5 \cdot 5}$ & + & + & + & + & + & + & + & + \\
\hline 20 & $\mathbf{M}$ & 55 & CAH & - & $10^{6}$ & + & + & + & + & + & + & + & + \\
\hline 21 & M & 49 & CAH & - & $10^{6.5}$ & + & + & + & + & + & + & + & + \\
\hline
\end{tabular}

Case numbers of patients in this Table correspond to those in Figure. Hist; liver histology of the patient; BTF, patient with a history of blood transfusion; H-R, pretreatment value of HCV RNA in the serum (copies $/ 50 \mu \mathrm{l}$ ); (end), the end point of interferon treatment. Other abbreviations as Table I. *Shows the time point when ALT became normalised. $†$ Shows the time point when first generation anti-HCV became negative. First generation anti-HCV antibody turned negative at the end of treatment in case 3, and turned negative within one year after the treatment in cases 4,6 , and 5 .

performed, and a prompt decrease in serum aminotransferase activities to normal or nearly normal was reported. ${ }^{3-6}$ Histological improvement, primarily the regression of lobular and periportal inflammation, was also reported. ${ }^{4}$ However, because of the frequent relapse of hepatitis after treatment has ended and because of the lack of markers to show the presence of non-A, non-B hepatitis virus, it was not known whether interferon treatment is really effective in clearing the virus from serum. Now, with the discovery of the virus $^{72021}$ and the development of a sensitive detection method of HCV RNA, ${ }^{10-16}$ evaluation of the effect of interferon on the virus has become feasible.

We examined serum HCV RNA during the course of interferon treatment and found that it became negative in 12 of 21 longterm ( 52 weeks) treatment patients $(57 \%)$. This may indicate that longterm interferon treatment with the dose used is actually effective in clearing the virus from the serum of patients with chronic hepatitis C. In contrast, HCV RNA became negative in only two of 22 patients (9\%) with hepatitis $\mathrm{C}$ undergoing short-term (eight weeks) interferon treatment. In comparison, then, this would indicate that the eight week interferon treatment at the dose used is too short to eradicate the virus except for a small proportion of cases. Among the patients who received such short-term treatment, a transient reduction of HCV RNA during the treatment, and then an increase again after the end of treatment, was seen. In those cases the virus might have decreased considerably, but still survived and replicated again in the liver and reappeared in serum. It might have been interesting to assess the effect of six month interferon treatment, because eight week treatment might be too short and 12 month treatment might be too long for some responsive patients. In fact, after this trial, we treated 193 patients for six months, and the efficacy rate was $29 \%$ (unpublished data).

Among the patients who underwent the 12 month treatment, the number whose $\mathrm{HCV}$
RNA became negative increased with the length of treatment. This suggests that a longer treatment period results in increased numbers of sustained responders if the dose of interferon is the same. This might also suggest either a time dependent or an accumulating dose dependent effect of interferon on HCV. To determine which of these is responsible for clearing the virus from serum, further studies with various doses are now under way.

The rate of sustained responders to longterm treatment in this study was high compared with other reports. ${ }^{56}$ One of the reasons for this must be the longer treatment period as described above. The rates of sustained responders have been reported to be higher in patients with longer periods of treatment. ${ }^{22} 23$ Our results were compatible with those reports.

In addition, there are several reports that showed that inclusion of patients with cirrhosis was associated with a lower sustained response rate to interferon treatment. ${ }^{24-27}$ In this study, comparatively few patients with cirrhosis (five cases) were included, so this might be another reason for the high sustained response rate to the longterm treatment.

Our study also showed that the patients who showed sustained response to the treatment tended to have lower pretreatment values of HCV RNA compared with those who did not. This suggests that the rate of sustained responders might also be influenced by the proportion of patients who have comparatively low values of HCV RNA among the treated patients.

Unusual genotype(s) of HCV might possibly be a reason for the high response rate. However, as proportions of $\mathrm{HCV}$ genotypes $1 \mathrm{a}, 1 \mathrm{~b}$, $2 \mathrm{a}, 2 \mathrm{~b}$, and undetermined were $0 \%, 63 \%$, $17 \%, 7 \%$, and $13 \%$, respectively (unpublished data) as determined by a method described by Okamoto et al, ${ }^{28}$ involvement of unusual genotype(s) is unlikely to be a cause of the high sustained response rate by the longterm treatment.

Among the cases treated by longterm interferon, there was one whose ALT value fell to 
normal range and remained so for 38 months, only to become abnormal again thereafter (Figure, left panel, Table III, case 14). In this case HCV RNA also decreased considerably, but returned to the pretreatment value even during the interferon treatment and remained higher thereafter. Although the mechanism of this normalisation of the ALT value despite the presence of $\mathrm{HCV}$ is unknown, it might be caused by the interferon treatment through the reduction of the amount of $\mathrm{HCV}$. Because of the presence of HCV RNA in serum, however, we carefully followed up this patient in anticipation of an ALT activity relapse, and in fact an increase did occur. So, even if longterm normalisation of the ALT activity is seen, careful follow up of such patients will be required when HCV RNA in serum remains positive, as the risk of relapse of the liver enzyme activity seems high.

Our results have suggested that once the virus is completely cleared from serum, ALT remains within a normal range even after the end of treatment. The ALT value may become normalised during the interferon treatment, but because of the frequent relapse of ALT after the end of treatment, ${ }^{3-6}$ it is difficult to predict when the treatment should be stopped. If the method of detecting HCV RNA is sensitive enough to find a small copy number of $\mathrm{HCV}$, however, the time point for stopping treatment might be predictable by the detection of HCV RNA. Therefore, the sensitivity of the detection method of HCV RNA is crucial. By using a comparatively insensitive method, HCV RNA may easily seem to have disappeared, only to reappear after the end of treatment. If this was the case, the detection of HCV RNA would be of little value for monitoring the clearance of the virus from serum. In this regard, we believe that our method is sufficiently sensitive.

Detection of anti-HCV antibody by a first generation assay system is also valuable for determining the effect of the treatment on chronic hepatitis $C$. The formation of antiHCV antibody, however, is a response of the patient to the viral infection, and first generation anti-HCV antibody was only detectable in $70-80 \%$ of non-A, non-B chronic hepatitis. ${ }^{829} 30$ In addition, the changes of antiHCV antibody caused by the treatment seem to be delayed compared with the changes of HCV RNA. This delay must be caused by the half life of the antibody. The detection of HCV RNA by RT-PCR seems more valuable in detecting the changes of $\mathrm{HCV}$ caused by the treatment than detection of anti-HCV antibody, although it is a method that is still in limited use in ordinary clinical laboratories. Recently, Brillanti et al reported that disappearance of IgM anti-HCV antibody might predict the sustained effect of interferon treatment, so the detection of IgM anti-HCV antibody might also be useful for monitoring the effect of interferon treatment. ${ }^{31}$ Easier techniques for detecting the viral antigen or neutralising antibody such as that against the envelope protein of HCV may be developed in the future. For the time being, the detection of HCV RNA by RT-PCR will remain as one of the most valuable tools for monitoring the effect of various treatment regimens on hepatitis $\mathrm{C}$.

1 Dienstag JL. Non-A, non-B hepatitis. I, Recognition, epidemiology, and clinical features. Gastroenterology 1983 85: 439-62.

2 Alter HJ. Transfusion-associated non-A, non-B, hepatitis: the first decade. In: Zuckerman AJ, ed. Viral hepatitis and the first decade. In: Zuckerman AJ, ed. Viral hepatitis
liver disease. New York: Alan R Liss, 1988: 537-42.

3 Hoofnagle JH, Mullen KD, Jones DB, Rustgi V, Bisceglie $\mathrm{AD}$, Peters $\mathrm{M}$, et al. Treatment of chronic non-A, non-B $\mathrm{AD}$, Peters $\mathrm{M}$, et al. Treatment of chronic non-A, non-B hepatitis with recombinant huma
Engl f Med 1986; 315: 1575-8.

4 Omata M, Ito Y, Yokosuka O, Imazeki F, Uchiumi K, Takano S, et al. Histological changes of the liver by treatment of chronic non-A, non-B hepatitis with recombinan leukocyte interferon alpha: comparison with histological changes in chronic hepatitis B. Dig Dis Sci 1989; 34 330-7.

5 Davis GL, Balart LA, Schiff ER, Lindsay K, Bodenheimer Jr HC, Perrilo P, et al. Treatment of chronic hepatitis C with recombinant interferon alpha. A multicenter randomized

6 Di Bisceglie AM, Martin P, Kassianides C, Lisker-Melman M, Murray L, Waggoner J, et al. Recombinant interferon alfa therapy for chronic hepatitis C. A randomized, alfa therapy for chronic hepatitis C. A randomized, double-blind, placeb

7 Choo Q-L, Kuo G, Weiner AJ, Overby LR, Bradley DW, Houghton $M$. Isolation of a CDNA clone derived from a blood borne non-A, non-B, viral hepatitis genome. Science 1989; 244: 359-62.

8 Kuo G, Choo QL, Alter HJ, Gitnick GL, Redeker AG, Purcell RH, et al. An assay for circulating antibodies to a major etiologic virus of human non-A, non-B hepatitis. Science 1989; 244: 362-4

9 van der Poel CL, Cuypers HMT, Reesink HW, Weiner AJ, Quan S, di Nello R, et al. Confirmation of hepatitis C virus infection by new four-antigen recombinant virus infection by new four-antigen reco

10 Kato N, Yokosuka O, Omata M, Hosoda K, Ohto $M$ Detection of hepatitis $C$ virus ribonucleic acid in the serum by amplification with polymerase chain reaction f Clin Invest 1990; 86: 1764-7.

11 Hosoda K, Yokosuka O, Omata M, Kato N, Ohto $M$. Detection and partial sequencing of hepatitis $C$ virus RNA in the liver. Gastroenterology 1991; 101: 766-71.

12 Weiner AJ, Kuo G, Bradley DW, Bonino F, Saracco G, Lee $C$, et al. Detection of hepatitis $C$ viral sequences in non-A non-B hepatitis. Lancet 1990; 335: 1-3.

13 Garson JA, Tedder RS, Briggs M, Tuke P, Glazebrook JA, Trute A, et al. Detection of hepatitis C viral sequences in blood donations by 'nested' polymerase chain reaction and prediction of infectivity. Lancet 1990; 335: 1419-22.

14 Okamoto $H$, Okada S, Sugiyama Y, Tanaka T, Sugai Y, Akahane $Y$, et al. Detection of hepatitis $C$ virus RNA by a Akahane $\mathrm{Y}$, et al. Detection of hepatitis $C$ virus RNA by a two-stage polymerase chain reaction with two pairs of primers deduced from the

15 Castillo I, Bartolome J, Navas S, Gonzalez S, Herrero M Carreno V. Virological and biochemical long-term followup of patients with chronic hepatitis $C$ treated with interferon. Hepatology 1994; 19: 1342-6.

16 Shindo M, Di Bisceglie AM, Cheung L, Shih JM, Baker B, Feinstone SM, et al. Changes in hepatitis $\mathrm{C}$ virus RNA in serum associated with alpha interferon therapy. Ann Intern Med 1991; 115: 700-4.

17 Okamoto H, Okada S, Sugiyama Y, Yotsumoto S, Tanaka $\mathrm{T}$, Yoshizawa $\mathrm{H}$, et al. The $5^{\prime}$-terminal sequence of the T, Yoshizawa H, et al. The 5'terminal sequence of the hepatitis

18 Kato N, Hijikata M, Ohtsuyama Y, Nakagawa M, Ohkoshi $\mathrm{S}$, Sugimura $\mathrm{T}$, et al. Molecular cloning of the human hepatitis $C$ virus genome from Japanese patients with nonA, non-B hepatitis. Proc Natl Acad Sci USA 1990; 87: 9524-8.

19 Kato N, Yokosuka O, Hosoda K, Ito Y, Ohto M, Omata M. Quantification of hepatitis $C$ virus by competitive reverse transcription-polymerase chain reaction: increase of the virus in advanced liver disease. Hepatology 1993; 18: 16-20.

20 Houghton M, Choo QL, Kuo G. European patent application. Application number 90302866.01990.

21 Kubo Y, Takeuchi K, Boonmar S, Katayama T, Choo QL, Kuo G, et al. A cDNA fragment of hepatitis $\mathrm{C}$ virus isolated from an implicated donor of post-transfusion non-A lated from an implicated donor of post-transfusion non-A, non-B hepati $10367-72$.

22 Hoofnagle J, Di Bisceglie AM, Shindo M. Antiviral therapy of hepatiti C - present and future. $\mathcal{F}$ Hepatol 1993; 17 S130-6.

23 Reichard O, Forberg U, Fryden A, Mattsson L, Norkrans $\mathrm{G}$, Sonnerborg $\mathrm{A}$, et al. High sustained response rate and clearance of viremia in chronic hepatitis $\mathrm{C}$ after treatmen with interferon-2b for 60 weeks. Hepatology 1994; 19: $280-5$.

24 Causse X, Godinot H, Chevallier M, Chosseqros P, Zoulim F, Ouzan D, et al. Comparison of 1 or $3 \mathrm{MU}$ of interferon alfa-2b and placebo in patients with chronic non-A non-B hepatitis. Gastroenterology 1991; 101: 497-502. 
25 Saracco G, Rosina F, Torrani Cerenzia MR, Lattore V, Chiandussi $\mathrm{L}$, et al. A randomized controlled trial of interferon alfa-2b as therapy for chronic non- $A$, non-B hepatitis. F Hepatol 1990; 11: S43-9.

26 Weiland O, Schvarcz R, Wejstal R, Norkrans G, Fryden A. Therapy of chronic post-transfusion non-A, non-B hepatitis with interferon alfa-2b: Swedish experience. hepatitis with interferon a

27 Camps J, Garcia-Granero M, Riezu-Boj JI, Larrea E, de Alava E, Civeira MP, et al. Prediction of sustained remission of chronic hepatitis $\mathrm{C}$ after 12-month course of alfa interferon. $\mathcal{F}$ Hepatol 1994; 21 : 4-11.

28 Okamoto H, Sugiyama Y, Okada S, Kurai K, Akahane Y, Sugai $\mathrm{Y}$, et al. Typing hepatitis $\mathrm{C}$ virus by polymerase chain reaction with type specific primers: application to clinical surveys and tracing infectious sources. $\mathcal{f}$ Gen Virol 1992; 73: 673-9.

29 Bruix J, Barbera JM, Calvet X, Ercilla G, Costa J, SanchezTapias JM, et al. Prevalence of antibodies to hepatitis C virus in Spanish patients with hepatocellular carcinoma and hepatic cirrhosis. Lancet 1989; ii: 1004-6.

30 Colombo M, Kuo G, Choo QL, Donato MF, Del Ninno E, Tommasini MA, et al. Prevalence of antibodies to hepatitis C virus in Italian patients with hepatocellular carcinoma. Lancet 1989; ii: 1006-8.

31 Brillanti S, Masci C, Ricci P, Miglioli M, Barbara L. Significance of IgM antibody to hepatitis $C$ virus in patients with chronic hepatitis C. Hepatology 1992; 15: 998-1001. 